\title{
ÜZENET MAI ISKOLÁINKBA
}

\author{
Pénzes Ferenc ${ }^{73}$
}

Ha élne, vajon mit üzenne mai iskoláinkba Ady Endre? Bíztatná-e „, a mindig újakat” a „,zord” küzdelemre? Történelmietlen kérdések, mondhatják sokan, hiszen nem tudhatjuk rájuk a választ. Mindenesetre az elmúlt négy-öt esztendöben a magyar települések közszolgáltatási szervezeti keretei alapvetö változásokon mentek keresztül - csakúgy, mint a közoktatás/köznevelés rendszere. Az alábbiakban igyekszem az egyik legfontosabb problémát exponálni: a köznevelés rendszerének elmúlt néhány éves átalakulását mind nemzeti, mind lokális perspektívából.

Röviden áttekintve azokat a folyamatokat, amelyek Magyarországon 1985 és 2010 között zajlottak le a közoktatás területén azt tapasztalhatjuk, hogy az ekkor született jogszabályok által helyi szintre kerültek a fenntartási és üzemeltetési/müködtetési feladatok, a tisztán helyi közügynek tekinthető önkormányzati funkciók és bizonyos államigazgatási funkciók. Mindez az önkormányzatiság és a helyi autonómia erősítését szolgálta ${ }^{74}($.$) . A korábban központi$ oktatásirányítást szinte teljes egészében egy decentralizált rendszer váltotta fel. Olyan kulcsfogalmakkal lehet leírni ezt az időszakot, mint rugalmas tantervi követelmények, fenntartói pluralizmus, intézményi autonómia, pedagógusi autonómia, valódi tantestületi döntési kompetencia. Ám a 2008-as ingatlanhitelezési és bankválságot követően 2010-ben hatalomra került pártok problematikusnak látták az előző időszak túlzott szabadságát szabadosságát.

A nemzeti köznevelésről ${ }^{75}$ és a Magyarország helyi önkormányzatairól szóló ${ }^{76}$ két törvényt egyazon napon, 2011. december 19-én fogadta el az Országgyülés. Ezek értelmében a helyi közügyek közül - az óvodai ellátás kivételével - kikerülnek a köznevelési feladatok, e funkció ellátását az állam veszi át. A köznevelés országos rendszerének központosítása része annak a politikai programnak, amely a közszektorban újfajta elszámoltatási viszonyokat kíván teremteni. Célja a rendszer hatékony müködtetése, a minőség egységesítése, a felzárkóztatás és a gazdasági-társadalmi fejlődést támogató szakképzés kialakítása. Eszközei az állami müködtetésbe-vétel (Klebelsberg Intézményfenntartó Központ - KLIK, tankerületek, Nemzeti Szakképzési és Felnőttképzési Hivatal - NSZFH, Szakképzési centrumok), a kiadások visszafogása (szektorálisan a GDP arányában történt ráfordítás a 2010-es 3,6\%-ról 2013-ban 2,3\%-ra csökkent), a pedagógus életpálya modell bevezetése (központi bérfinanszírozással és bérrendezéssel), valamint a duális képzés alkalmazása a szakképzésben. A köznevelési intézmények tekintetében kettéválnak a fenntartási és a müködtetési feladatok. Ez praktikusan két dolgot jelent: egyrészt, az intézmények üzemeltetési feladatai megoszlanak a központi és a helyi szint között, másrészt, az immár állami alkalmazásba kerülö pedagógusok és szakmai segítők bérét a központi költségvetés finanszírozza. Az iskolaigazgatót központilag nevezik

\footnotetext{
A tanulmány a Magyar Tudományos Akadémia és a Debreceni Egyetem Állam- és Jogtudományi Kar közös, MTA-DE Közszolgáltatási Kutatócsoportjának a Területi közszolgáltatások szabályozásai címü projektje keretében készült. A projekt leírására 1.: Horváth M.T.: Szempontok a területi közszolgáltatások regulációs változásainak vizsgálatához. In: HMT (szerk.) Kilengések. Közszolgáltatási változások. Budapest: Dialóg Campus, 2013. 9-25. old.

${ }^{73}$ Pénzes Ferenc, PhD, egyetemi adjunktus, DE ÁJK

${ }^{74}$ PÉTERI Gábor: Újraközpontosítás a közoktatásban, Educatio (XXIII. évf.) 1. sz. /Mérleg 2010-2014/ 14-16.

75 2011. évi CXC. törvény a nemzeti köznevelésröl

${ }^{76}$ 2011. évi CLXXXIX. törvény Magyarország helyi önkormányzatairól
} 
ki, akinek az intézményében megüresedő státuszok betöltésében csak javaslattevő joga maradt. Mivel az igazgató csupán a szakmai (oktatási-nevelési) feladatokért tehető felelőssé, az intézmény üzemeltetése visszakerült az önkormányzati hivatal, vagy más helyi költségvetési szerv, településüzemeltető gazdasági társaság kezébe. Az iskolák ellenőrzését végző megyei kormányhivatalok, az oktatási hivatal, valamint a KLIK - a központi kormányzat területi egységeiként - közigazgatási értelemben hierarchikus függelmi rendszerben müködnek, vagyis közvetlen lakossági befolyás nélkül. Ennek a rendszernek a legszilárdabb eleme a központi kormányzat és az iskola közötti direkt és egyirányú kapcsolat lett. Ekként pedig az iskolahasználók és az oktatási intézmény közötti kapcsolat úgyszintén gyengült, a szabad iskolaválasztás lehetőségének fennmaradása és az - iskolaszékeknél jóval gyengébb befolyással bíró - intézményi tanácsok múködése mellett is. ${ }^{77}$

Az elmúlt időszakban tehát az átalakított köznevelés, a megváltozott igazgatási és helyi önkormányzati rendszer új viszonyokat teremtett, nézzük meg, hogyan ment végbe ez az átszervezés Hajdúböszörményben. ${ }^{78} \mathrm{~A}$ köznevelés megszervezése alapvetően a demográfiai és a gazdasági viszonyoktól függ.
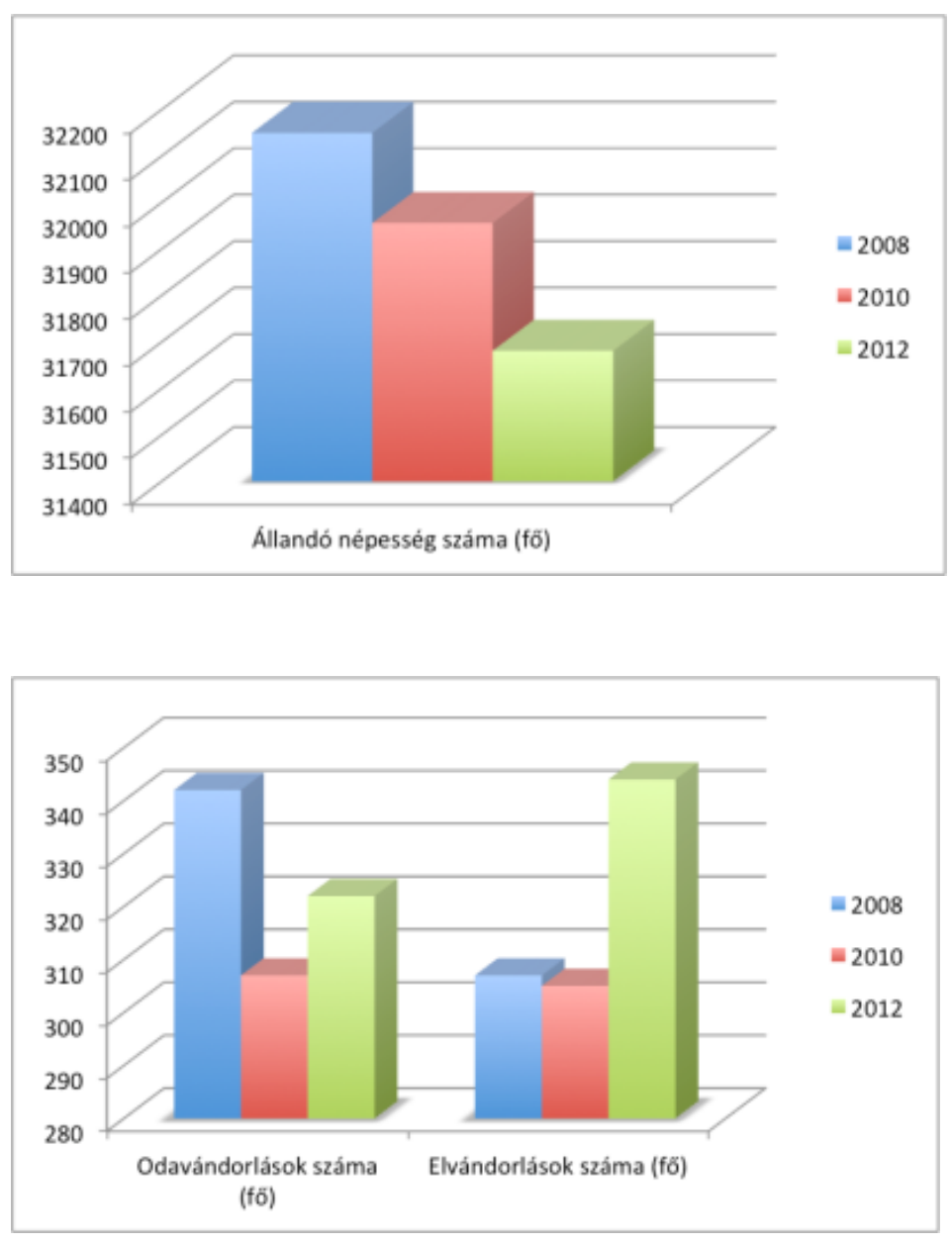

Hajdúböszörményben 2008 óta csökken a népesség, elsősorban a természetes fogyásnak köszönhetően, bár ezt némileg kompenzálta az elsősorban a településre beköltözők relatíve jelentős száma. Az egyenleg így is negatív: összességében 1,5\%-kal lett kisebb a település lélekszáma. A korfa is átalakult a településen, míg a 17 évnél fiatalabbak aránya $20 \%$ körülire csökkent, addig a 60 évnél idősebbeké 21\%-ra nőtt (Forrás: TEIR).

\footnotetext{
${ }^{77}$ Vö. Péteri: Újraközpontositás a közoktatásban. 14-18.

${ }^{78}$ PÉTERI GÁBOR: Köznevelés: együttmüködésre ítélve. In: Horváth M. Tamás-Bartha Ildikó: Gyürük és sugarak. Mit nyújt egy magyar város. Dialóg Campus Kiadó. Budapest-Pécs, 2014. 153-177.
} 


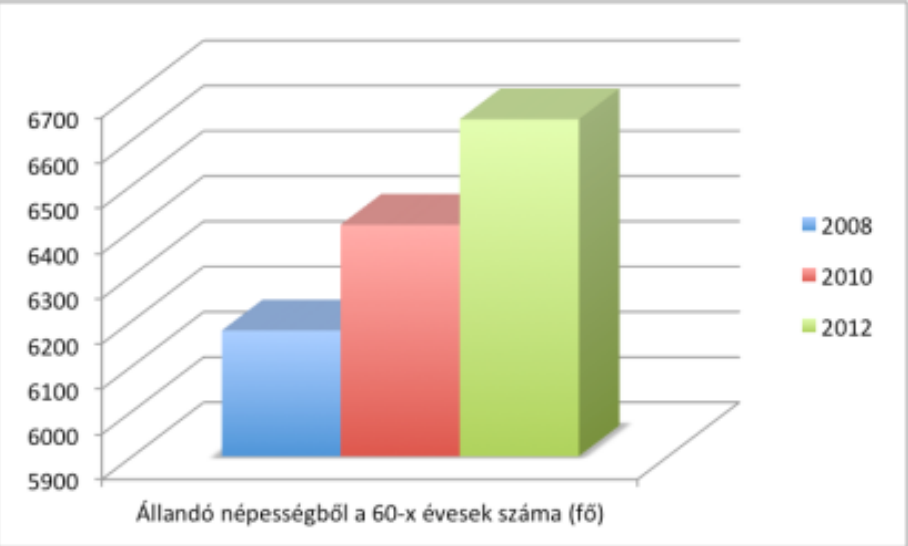

A közfoglalkoztatásnak és a javuló gazdasági lehetőségeknek köszönhetően 2010 és 2014 között 10\%-kal csökkent a munkanélküliség.

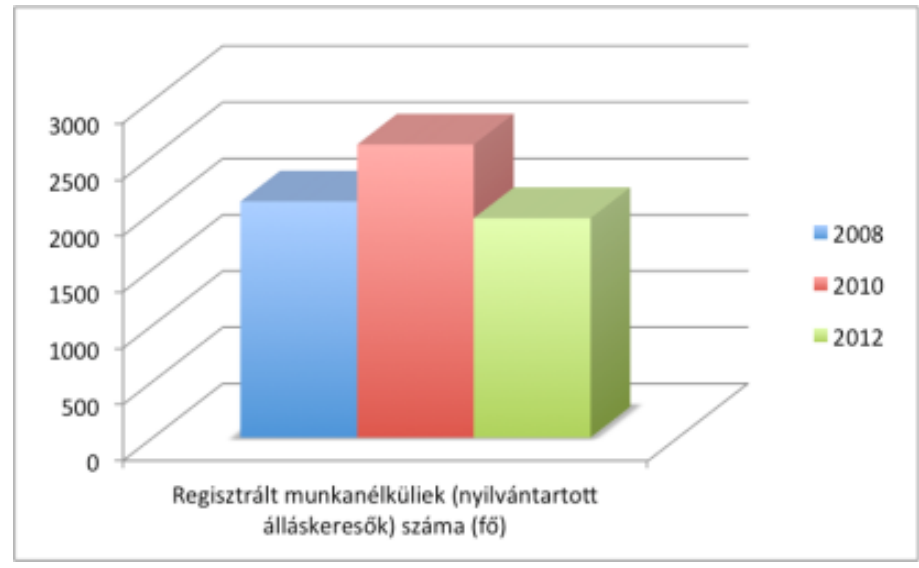

A diagramok forrása: Az MTA-DE Közszolgáltatási Kutatócsoport Ténymegállapitó tanulmányok Hajdúböszörményben 2014-15 c. alprojektjének adatbankja

Hajdúböszörményben 18 köznevelési intézmény müködik, s ehhez jönnek még ezek tagintézményei és telephelyei. Ezek között van öt óvoda, hét általános iskola (ebböl kettő alapfokú müvészetoktatási intézmény), két gimnázium, két szakképző iskola, egy középiskolai kollégium, és egy sajátos nevelési igényü gyerekeket foglalkoztató intézmény, amely gyermekotthont is müködtet. ${ }^{79}$ A települési oktatási rendszer átalakítása már 2007-ben elkezdődött. Ezen első „intézményhálózat racionalizálásnak” az volt az oka, hogy megváltozott a közoktatás állami támogatása. A korábbi tanulói fejkvótát felváltotta a teljesítménymutatón alapuló finanszírozás. Így az önkormányzatok arra kényszerültek, hogy a települési intézményhálózatot ésszerüsítsék. Az iskolabezárások és átszervezések miatt sok tanuló bejárásra kényszerült, amit vagy helyi buszjáratokkal, vagy szerződéses buszokkal oldottak meg. Az átszervezések ezen első hullámával a város már elvégezte azokat az összevonásokat, amelyeket a 2012-től zajló államosítások célul tüztek ki. Az utóbbi évek átszervezései megszüntették a korábban a középfokú képzésben oly fontosnak tartott térségi együttmüködési formákat is. A városban két, a helyi református egyházközség által fenntartott intézmény van: az 1995-ben alapított Baltazár Dezső Általános Iskola és a 2006 óta müködő Jó Pásztor Református Óvoda. Ezek ugyan versenytársai az állami-önkormányzati intézményeknek, de helyi igényt is kielégítenek: egyrészt felekezeti kötődésük folytán, másrészt magasabb szintű ellátásukkal is. Az iskolák önálló gazdálkodásának időszakában fontos volt a saját bevételek növelése és ez a trend részben megmaradt az állami fenntartásba

\footnotetext{
${ }^{79}$ Péteri Gábor: Köznevelés: 156-158.
} 
vételt követően is. A korábbi iskolai alapítványok - amelyek 2013-at követően függetlenedtek az állami fenntartásba vett intézményektől - még ma is fontos forrást biztosítanak az oktatáshoz kapcsolódó feladatok ellátásához.

Összességében azt mondhatjuk, hogy az oktatáspolitikai kormányzat az ágazat problémáit a 2012-től elkezdődő átalakulással vélte megoldhatónak. Ennek pozitív hozadékai között említhető, hogy a központilag kinevezett tanárok és iskolaigazgatóik kapcsolata most sokkal inkább szakmai, mintsem munkaerő-piaci. A stratégiai tervezést is jobban lehetővé teszi egy kompaktabb és hierarchikusan felépülő oktatási rendszer, s ez ráadásul nem, vagy kevésbé kötődik a helyi érdekekhez. Egy vertikális szervezet „,igazságosabban” oszthatja el az ágazatra szánt erőforrásokat, elvileg regionális és lokális értelemben jobban érzékelheti és súlyozhatja azt, hogy éppen hol szükséges többlet ráfordítás. Ezekkel az elönyökkel szemben a mérleg másik serpenyőjébe talán súlyosabb dolgok kerülnek. A bürokratikus irányítás esetén minden a csúcson dől el, az iskolák szintjén megszünik a korábban átfogó jellegű vezetői felelősség. A tankönyvellátás és a költségelszámolások problémái, a tantervi és az irányításigazdálkodási változások fordulatai borzolták és borzolják a kedélyeket. Ráadásul az oktatásügy makrostruktúrája igen kevéssé innovatív és kreatív. Végül, ám korántsem utolsó sorban, így a helyi kezdeményezések, a civilek és laikusok (a szülők, az érdekcsoportok, az önkormányzatok, a piaci szereplők), az önkéntesek kiszorulnak a helyi oktatási intézmények életéböl. ${ }^{80}$

Kérdéses továbbá, hogy az állami fenntartású intézmények mennyire lesznek motiváltak a továbbiakban külső források megszerzésére. Bizonyos fokú zavart okoz mind az iskolák, mind az önkormányzat számára az, hogy az oktatási intézmények fenntartása, müködtetése és szakmai felügyelete meglehetősen összekuszálódott a város tekintetében, ráadásul ezt a zavart csak tetézte, hogy korábbi pedagógusok és a polgármesteri hivatal tisztségviselői lettek tankerületi, vagy KLIK-es alkalmazottak, vezetők. A helyi iskolaüzemeltetést jelenleg két szervezet látja el: egyrészt költségvetési formációként a Városüzemeltetési Intézmény (VÜZI), illetve magántulajdonú, gazdasági társasági formában müködő TÖMB 2002 Kft. A szakképzés terén a Széchenyi István Mezőgazdasági Szakképző Iskolát és Kollégiumot 2013tól a Földművelésügyi Minisztérium vette fenntartásába, míg a Veress Ferenc Szakképző Iskola előbb a megyei KLIK-hez került, majd 2015. július 1-jétől a Nemzetgazdasági Minisztérium országos hatáskörü a szak- és felnőttoktatást irányító szerve, a Nemzeti Szakképzési és Felnőttképzési Hivatal vette átaműködtetését.

Konklúzióként elmondható az, hogy a magyar közoktatási rendszer utóbbi három-négy éves átalakulásának az iránya nemcsak a korábban követett decentralizációs iránnyal ellentétes, hanem Európa más országaiban követett gyakorlattal is. ${ }^{81}$ Adynak a mai iskolákba küldött - a leírtakra rácáfoló módon optimista - üzenete pedig valószínủleg úgy hangzana: a legfontosabb az, hogy az élet „zengje be”, hassa át az iskolát, s ebből fakadóan az „élet is derüs iskola" legyen!

\footnotetext{
${ }^{80}$ Vö. Kozma Tamás: A központosítás haszna és ára. Educatio (XXIII. évf.) 1. sz. /Mérleg 2010-2014/9-12. o.; Péteri: Újraközpontosítás a közoktatásban. 24-25. o.; Péteri Gábor: Területi közszolgáltatások szabályozási modelljei: a közoktatás. In: Horváth M. Tamás (szerk.): Külön utak. Közfeladatok megoldásai. Dialóg Campus Kiadó. Budapest-Pécs. 76-79. o.; Péteri: Köznevelés. 174-175.

${ }^{81}$ Vö. Péteri: Területi közszolgáltatások szabályozási modelljei. 77.
} 